\title{
Modulating the phenology and yield of camelina sativa $L$. by varying sowing dates under water deficit stress conditions
}

\author{
Ejaz Ahmad Waraich ${ }^{1^{*}}$,Zeeshan Ahmed ${ }^{1}$, Rashid Ahmad ${ }^{1}$ and Rana Nauman Shabbir ${ }^{2}$ \\ ${ }^{1}$ Department of Agronomy, University of Agriculture, Faisalabad \\ ${ }^{2}$ Department of Agronomy, Faculty of Agriculture Science and Technology, Bahauddin Zakariya University, Multan
}

\begin{abstract}
Camelina (Camelina sativa L.) an oilseed crop has emerged as a potential source for biofuels and bio-products. Camelina is an economic crop due to its less requirements of agronomic inputs as compared to other oilseed crops. However, it is direly required to evaluate the adaptability of camelina and characterize its production potential. Therefore, a pot experiment was carried out in rain out shelter at the Department of Agronomy, University of Agriculture, Faisalabad, Pakistan to optimize appropriate sowing date with respect to growth and yield potential of different genotypes of camelina under drought stress. Completely randomized design with factorial arrangements was adopted. Three sowing dates with the difference of 10 days $\left(\right.$ November $13^{\text {th }}, 23^{\text {rd }}$ and December $\left.03^{\text {rd }}\right)$, two water regimes (100\% FC and 60\% FC) and two camlena genotypes (611 and 618) were used in this experiment. Results indicated that camelina growth and yield related traits were significantly influenced by difference in sowing dates and water regimes. Maximum leaf area index (LAI), crop growth rate (CGR), leaf area duration (LAD), net assimilation rate (NAR) and yield related traits were recorded with early sowing (13 ${ }^{\text {th }}$ November) which was followed by sowing on $23^{\text {rd }}$ November and least values of these variables were recorded in late sowing (December $\left.03^{\text {rd }}\right)$. Plants grown under water deficit conditions $(60 \% \mathrm{FC})$ showed the decreased values of LAI, CGR, LAD, NAR and yield related attributes as compared to normally irrigated plants $(100 \%$ FC). However, the response of genotypes of camelina 611 and 618 remained statistically similar to each other.
\end{abstract}

Keywords: Camelina, sowing dates, Crop growth rate, Net assimilation rate, water stress

\section{Introduction}

Camelina, is an annual oilseed crop with short lifecycle and belongs to Mustard family (McVay and Khan, 2011). Its lifecycle normally lasts 90-110 days from emergence to maturity (Zubr, 1997). Oil content of camelina seed ranges between 38-44\% (Vollmann et al., 2007). Major portion of seed oil (about 90\%) consists of polyunsaturated fatty acids, making camelina an important source of omega-3 fatty acids (Vollmann et al., 2007; Hrastar et al., 2009). In recent decade camelina has emerged as a low agricultural input requiring crop with minimum cost of production (Gesch and Cermak, 2011). Camelina requires low nitrogen input as compared to canola and sunflower (Putnam et al., 1993). Camelina oil has also been considered as a feed stock for biodiesel (Aurore et al., 2003) and investigations are underway for aviation fuel (Shonnard et al., 2010). Camelina oil and meal is also used in animal feeds (Moloney et al., 2001). Camelina oil has wide industrial applications such as cosmetics, soaps, paints and resins (Pilgeram et al., 2007).

Sowing date is an important requisite in crop production which determines the timing and duration of vegetative and reproductive growth phases of the crop and ultimately the crop yield and seed quality (Dornbos, 2002; Bhuiyan et al., 2008). Selection of optimum sowing date positively links the climatic conditions with plant growth processes (Walton and Bowden, 1999; Hakan-ozer and Unsal, 1999). Previous studies conducted on sowing date of camelina under different environments provided varied results. In eastern Canada, sowing date could not affect the seed yield of camelina (Urbaniak et al., 2008). However, Pavlista et al. (2011) obtained maximum seed yields of camelina when planted at the end of March to mid-April. Whereas, Gesch and Cermack (2011) planted camelina in early October and obtained higher seed and oil yields. Thus establishing a suitable sowing date would be helping in maximizing camelina productivity for a given region. Water being an important abiotic element restricts crop production in many parts of the world (Araus et al., 2002). Physiological processes in plants like cell and tissue growth, photosynthesis and cell turgor, are directly influenced by water (Reddi and Reddi, 1995). In Pakistan mostly crops are damaged due to low and erratic rainfall which results in water shortage. About $60-100 \%$ yield losses has been reported due to prolonged water shortage in

*Email: uaf_ewarraich @ yahoo.com 
different crops (Singh et al., 2002). Evaluation and introduction of new oilseed crops with high yielding potential under scarce water resources availability is the only option to rescue small scale farmers for increased income (Tabassum, 2004). The aim of this study was to evaluate the growth and yield potential of camelina at varying sowing dates and different water levels in agroclimatic conditions of Faisalabad Pakistan.

\section{Materials and Methods}

A pot study was carried out in rain out shelter to investigate the effect of different sowing dates $\left(13^{\text {th }}\right.$ November, $23^{\text {rd }}$ November and $03^{\text {rd }}$ December) on the growth and production of camelina sativa genotypes under well-watered (100\% field capacity) and water deficit (60\% field capacity) conditions. The experiment was conducted in completely randomized design with factorial arrangement having three replicates in the department of Agronomy, University of Agriculture, Faisalabad. Seeds of camelina genotypes (611 and 618) were acquired from the Department of Plant Breeding and Genetics University of Agriculture, Faisalabad. Randomly selected 20 seeds of each cultivar were sterilized for five seconds with $5 \%$ sodium hypochlorite solution, washed them with distilled water and then air dried. Before sowing the soil (sand) was sun dried and sieved. The field capacity of sand was determined by gravimetric method. A random air dried screened sand sample was taken in a cylinder. Surface of sand was covered with filter paper and poured a small quantity of water to obtain uniform movement of water. Put the wet sand sample in a pre-weighed dish and then recorded the weight of sand plus dish. Sand was dried at $100{ }^{\circ} \mathrm{C}$ for 24 hrs. Then weighed the oven dried sand and dish. The gravimetric moisture content was calculated following formula (Bethlahmy and Nedavia, 1952; Gardner and others, 2001).

Gravimetric Moisture Content $=$ wet weight - dry weight $/$ dry weight - dish weight

Each plastic pot $(15 \mathrm{~cm}$ dia $\times 11 \mathrm{~cm}$ length $)$ rapped with plastic bag was filled with $2 \mathrm{~kg}$ of sand and 20 seeds of both Camelina sativa genotypes $\left(\mathrm{V}_{1}: 611\right.$ and $\mathrm{V}_{2}: 618$ ) were sown on respective sowing dates in 2015 and irrigated with distilled water. At the initial stage of experiment the pots were irrigated properly to obtain good germination and emergence. Before imposing water stress thinning was done 14 days after germination and uniform sized 10 healthy plants were maintained in each pot. Twenty one (21) days after sowing of each treatment (keeping in view the respective sowing dates) water deficit stress was imposed by applying $300 \mathrm{~mL}$ of DI water to maintain $60 \%$ FC whereas $100 \%$ FC was maintained by the application of $500 \mathrm{~mL}$ water to the respective pots. To maintain field capacity levels $(100 \%$ FC and $60 \%$ FC) pots were weighed on electrical balance daily at about 9:00 am, calculated the amount of water consumed in evapotranspiration and watered until the pot weight reached to pre-determined weight. Nitrogen (50 $\mathrm{kg} \mathrm{ha}^{-1}$ ), phosphorus (30 kg ha ${ }^{-1}$ ) and potassium (60 kg $\mathrm{ha}^{-1}$ ) were applied at the time of sowing using urea, single superphosphate and muriate of potash respectively. During the experimentation, leaf area index (LAI) was measured by using the formula given by (Watson, 1947).

\section{$\mathrm{LAI}=$ Leaf area $/$ ground surface area}

Crop growth rate (CGR) $\left(\mathrm{g} \mathrm{m}^{-2} \mathrm{~d}^{-1}\right)$ and leaf area duration (LAD) (days) and Net assimilation rate (NAR) $\left(\mathrm{g} \mathrm{m}^{-2} \mathrm{~d}^{-1}\right)$ were calculated by using the formula given below (Hunt, 1978).

$$
\begin{gathered}
\mathrm{CGR}=\left(\mathrm{W}_{2}-\mathrm{W}_{1}\right) /\left(\mathrm{T}_{2}-\mathrm{T}_{1}\right) \\
\mathrm{LAD}=\left(\mathrm{LAI}_{1}+\mathrm{LAI}_{2}\right)\left(\mathrm{T}_{2}-\mathrm{T}_{1}\right) / 2 \\
\mathrm{NAR}=(\mathrm{TDM}) /(\mathrm{LAD})
\end{gathered}
$$

$\mathrm{LAI}_{1}=$ Leaf area index at first time in the crop growing season, $\mathrm{LAI}_{2}=$ Leaf area index at last time at crop maturity, $\mathrm{W}_{1}=$ oven dried weight at first sampling, $\mathrm{W}_{2}=$ oven dried weight at second sampling, $\mathrm{T}_{1}=$ time of first sampling, $\mathrm{T}_{2}=$ time of second sampling. TDM= Total dry matter accumulated $\left(\mathrm{W}_{2}-\mathrm{W}_{1}\right)$. Moreover yield and yield contributing parameters were measured and data organized for statistical analysis.

\section{Statistical analysis}

Data were collected and analyzed by using Fisher's Analysis of Variance technique with Statistix software 9.1 package. Treatment means were compared through Least Significant Difference (LSD) test at $5 \%$ probability (Steel et al., 1997).

\section{Results}

\section{Leaf area index}

Different sowing dates and water levels had a significant effect on leaf area index of camelina genotypes throughout the sampling period. All interaction effects were statistically non-significant. Analyzed data revealed that maximum leaf area index (2.19) was recorded at 65 day after sowing in the early sowing (November, $13^{\text {th }}$ ) treatment (Figure 1). In case of water deficit stress normal watering $(100 \% \mathrm{FC})$ achieved maximum value (2.08) of LAI at 65 days after sowing (Fig.1). Leaf area index in both camelina genotypes was statistically similar across different sowing dates and water regimes (Table 1). 
Table 1: Mean square values from analysis of variance of leaf area index of two camelina genotypes under different sowing dates and water deficit stress

\begin{tabular}{llllll}
\hline Source of Variation & d.f & LAI-1 & LAI-2 & LAI-3 & LAI-4 \\
\hline Plant densities (Pd) & 2 & $0.11227 * *$ & $0.21601 * *$ & $0.2640 * *$ & $0.21744 * *$ \\
Varieties & 1 & $0.0007 \mathrm{NS}$ & $0.000 \mathrm{NS}$ & $0.0051 \mathrm{NS}$ & $0.0002 \mathrm{NS}$ \\
Stress & 1 & $0.03868^{* *}$ & $0.13080^{* *}$ & $0.1667 * *$ & $0.1456^{* *}$ \\
Pd*Variety & 2 & $0.0006 \mathrm{NS}$ & $0.0013 \mathrm{NS}$ & $0.0002 \mathrm{NS}$ & $0.0004 \mathrm{NS}$ \\
Pd*Stress & 2 & $0.005 \mathrm{NS}$ & $0.0001 \mathrm{NS}$ & $0.0008 \mathrm{NS}$ & $0.0007 \mathrm{NS}$ \\
Variety *Stress & 1 & $0.0009 \mathrm{NS}$ & $0.0002 \mathrm{NS}$ & $0.0001 \mathrm{NS}$ & $0.0063 \mathrm{NS}$ \\
Pd*Variety* Stress & 2 & $0.002 \mathrm{NS}$ & $0.0001 \mathrm{NS}$ & $0.0004 \mathrm{NS}$ & $0.0031 \mathrm{NS}$ \\
Error & 24 & 0.0029 & 0.02399 & 0.02932 & 0.01813 \\
\hline
\end{tabular}

Table 2: Mean square values from analysis of variance of crop growth rate of camelina genotypes under different sowing dates and water deficit stress.

\begin{tabular}{lllll}
\hline Source of Variation & d.f & CGR-1 At $\mathbf{1}^{\text {st }}$ harvest & CGR-2 At $^{\text {nd }}$ harvest & CGR-3At3 $^{\text {rd }}$ harvest \\
\hline Plant densities $(\mathrm{Pd})$ & 2 & $7.9542^{* *}$ & $2.5494^{* *}$ & $4.5129^{* *}$ \\
Varieties & 1 & $0.0121 \mathrm{NS}$ & $0.0001 \mathrm{NS}$ & $0.0030 \mathrm{NS}$ \\
Stress & 1 & $0.4669^{* *}$ & $0.3927^{* *}$ & $1.8723^{* *}$ \\
Pd*Variety & 2 & $0.0963 \mathrm{NS}$ & $0.0016 \mathrm{NS}$ & $0.0013 \mathrm{NS}$ \\
Pd*Stress & 2 & $0.0171 \mathrm{NS}$ & $0.0004 \mathrm{NS}$ & $0.0276 \mathrm{NS}$ \\
Variety *Stress & 1 & $0.0245 \mathrm{NS}$ & $0.0001 \mathrm{NS}$ & $0.004 \mathrm{NS}$ \\
Pd*Variety* Stress & 2 & $0.0246 \mathrm{NS}$ & $0.008 \mathrm{NS}$ & $0.0022 \mathrm{NS}$ \\
Error & 24 & 0.0271 & 0.0653 & 0.0665 \\
\hline
\end{tabular}

$*=$ Significant at 0.05 probability level, $* *=$ Significant at 0.01 probability level, NS $=$ Non significant
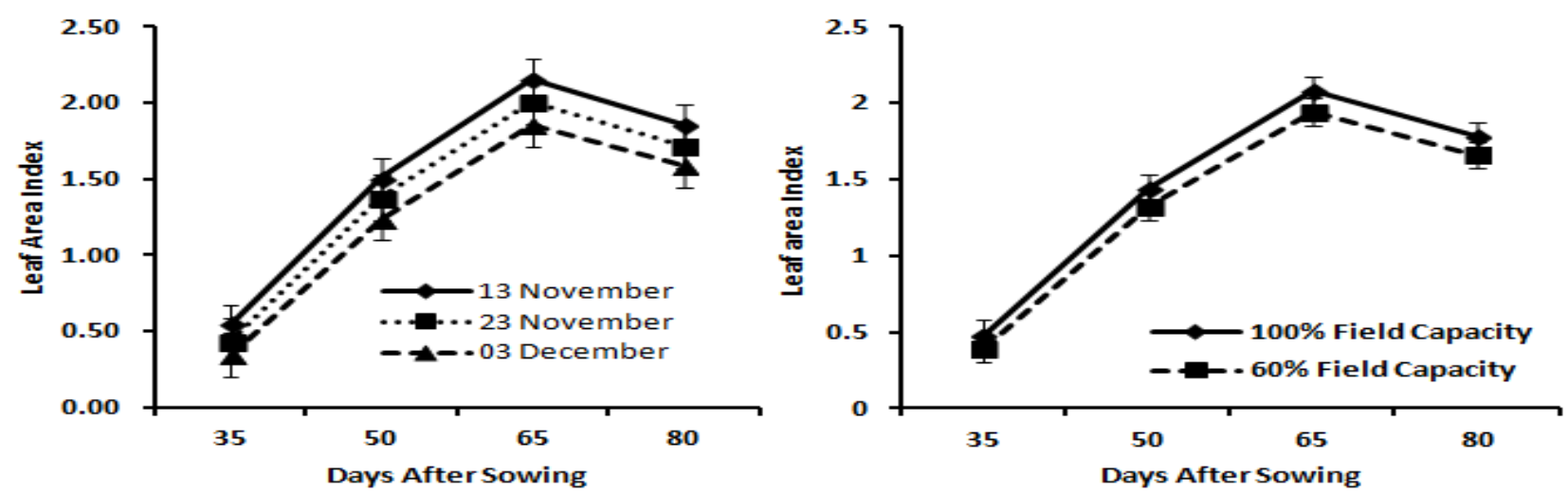

Figure 1: Leaf area index of Camelina sativa as affected by sowing date and water deficit stress

\section{Crop growth rate $\left(\mathrm{g} \mathrm{m}^{-2} \mathrm{~d}^{-1}\right)$}

Crop growth rate is an important tool for the growth analysis of different field crops .CGR represents the gain in total plant dry biomass per unit of land in unit time. Statistical analysis of data indicated significant differences in CGR for sowing date and irrigation water levels. The highest crop growth rate $\left(10.72 \mathrm{~g} \mathrm{~m}^{-2} \mathrm{~d}^{-1}\right)$ was recorded when crop was sown on $13^{\text {th }}$ November (Figure 2). Decrease in crop growth was noted with the increase of water deficit stress. Highest CGR $\left(10.17 \mathrm{~g} \mathrm{~m}^{-2} \mathrm{~d}^{-1}\right)$ was observed at $100 \%$ FC about 65 days after sowing (Fig.2).
There was no significant difference between camelina genotypes regarding CGR (Table 2).

\section{Leaf area duration (Days)}

Analyzed data revealed that different sowing dates and water levels had significantly affected the LAD of camelina genotypes. No interaction effect was significant. Maximum LAD (68 days) was recorded in the treatment where crop was grown on $13^{\text {th }}$ November (Figure 3 ). Between the water levels, $100 \%$ FC generated significantly higher LAD value (58 days) as compared to $60 \% \mathrm{FC}$ having LAD of 50 days 
Table 3: Mean square values from analysis of variance of leaf area duration of camelina genotypes under different sowing dates and water deficit stress

\begin{tabular}{llll}
\hline Source of Variation & \multicolumn{1}{c}{ d.f } & \multicolumn{1}{c}{ LA } & NAR \\
\hline Plant densities (Pd) & 2 & $645.78^{* *}$ & $10.02^{* *}$ \\
Varieties & 1 & $0.046 \mathrm{NS}$ & $0.0047 \mathrm{NS}$ \\
Stress & 1 & $598.61^{* *}$ & $0.7773^{* *}$ \\
Pd*Variety & 2 & $9.24 \mathrm{NS}$ & $0.0013 \mathrm{NS}$ \\
Pd*Stress & 2 & $21.80 \mathrm{NS}$ & $0.0125 \mathrm{NS}$ \\
Variety *Stress & 1 & $5.003 \mathrm{NS}$ & $0.001 \mathrm{NS}$ \\
Pd*Variety* Stress & 2 & $15.09 \mathrm{NS}$ & $0.0012 \mathrm{NS}$ \\
Error & 24 & 31.50 & 0.0313 \\
\hline \multicolumn{2}{l}{$*$ Significant at 0.05 probability level, ** = Significant at 0.01 probability level, NS = Non significant }
\end{tabular}
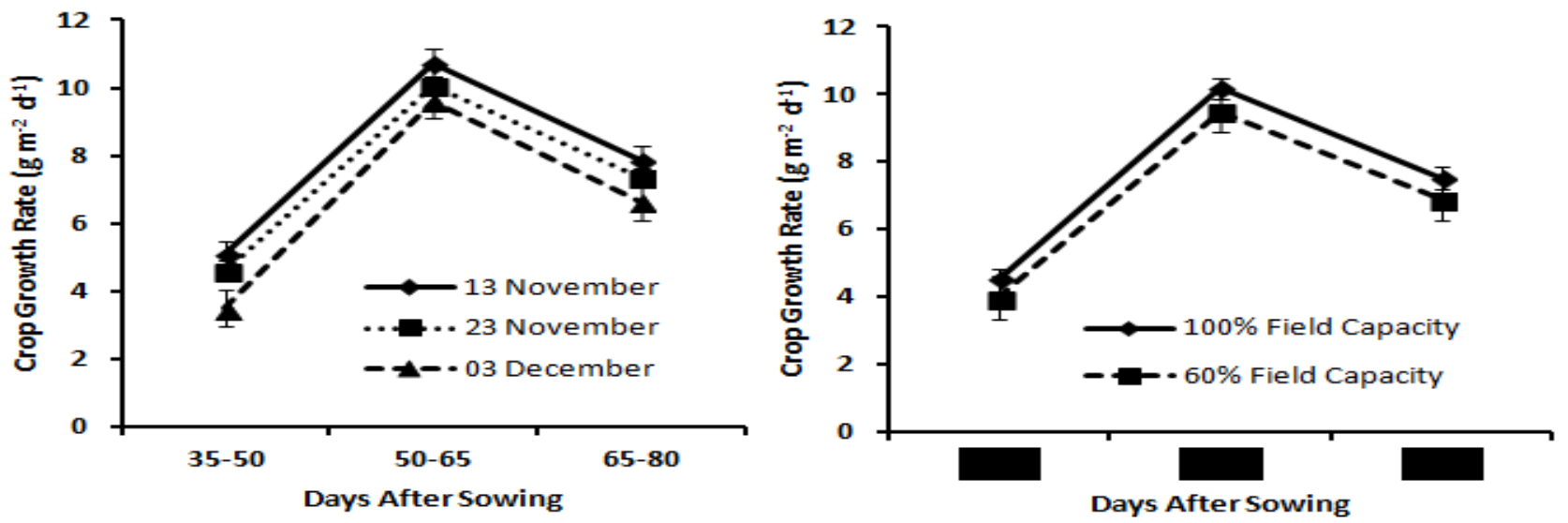

Figure 2: Crop growth rate of Camelina sativa as affected by sowing date and water deficit stress
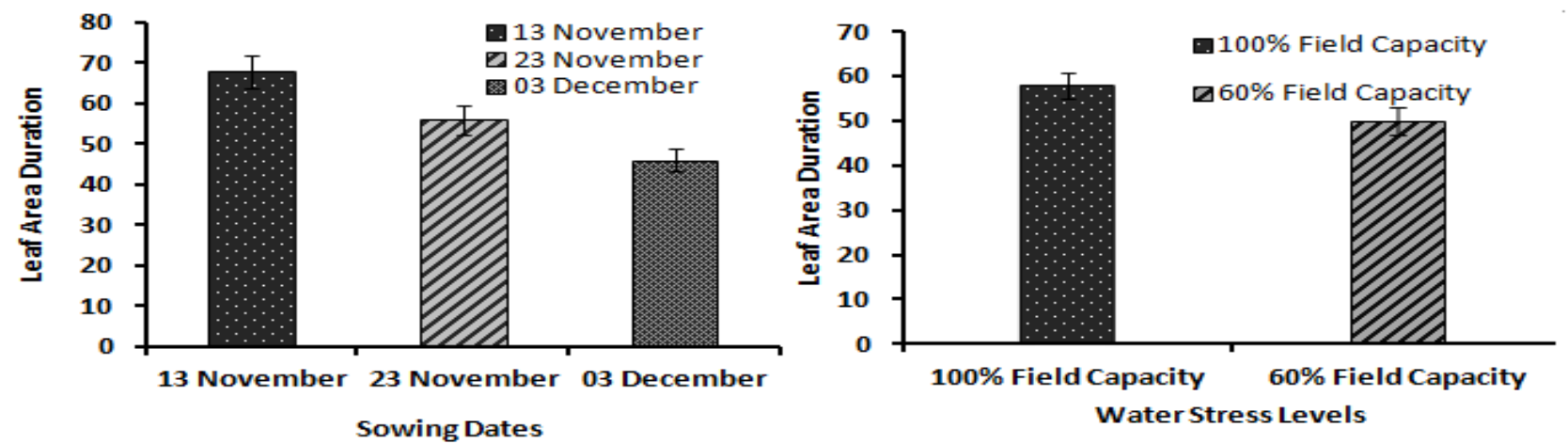

Figure 3: Leaf area duration of Camelina sativa as affected by sowing date and water deficit stress

(Figure 3). Camelina genotypes did not differ significantly for LAD (Table 3).

\section{Net assimilation rate $\left(\mathrm{g} \mathrm{m}^{-2} \mathrm{~d}^{-1}\right)$}

Statistical data indicated that different sowing dates and water levels had significant effect on net assimilation rate of two camelina genotypes. All the possible interaction effects were non-significant. Among different sowing dates, the plants sown at $13^{\text {th }}$ November showed maximum value $\left(5.4 \mathrm{~g} \mathrm{~m}^{-2} \mathrm{~d}^{-1}\right)$ for NAR than other sowing dates (Figure 4). Likewise, $100 \%$ FC treatment produced the highest NAR value (4.95 $\mathrm{g} \mathrm{m}^{-2} \mathrm{~d}^{-1}$ ) as compared to $60 \%$ FC level (Fig.4). There was no significant difference between camelina genotypes.

\section{Yield and yield components}

The results from the analysis of variance revealed that significant differences were observed between the main 
Table No 4: Seed yield and yield components of camelina genotypes as affected by different sowing dates and water deficit stress

\begin{tabular}{llllll}
\hline Treatments & $\begin{array}{l}\text { Plant height } \\
(\mathbf{c m})\end{array}$ & $\begin{array}{l}\text { Number of } \\
\text { branches/plant }\end{array}$ & $\begin{array}{l}\text { Number of } \\
\text { pods/plant }\end{array}$ & $\begin{array}{l}\text { 1000-seed } \\
\text { weight (g) }\end{array}$ & Seed yield/pot (g) \\
\hline Sowing Dates & & & & & \\
$\mathrm{Sd}_{1}\left(13^{\text {th }}\right.$ November) & $74.25 \mathrm{a}$ & $9 \mathrm{a}$ & $87 \mathrm{a}$ & $1.31 \mathrm{a}$ & $3.99 \mathrm{a}$ \\
$\mathrm{Sd}_{2}\left(23^{\text {rd }}\right.$ November $)$ & $66.75 \mathrm{~b}$ & $8 \mathrm{~b}$ & $79 \mathrm{~b}$ & $1.23 \mathrm{~b}$ & $3.77 \mathrm{~b}$ \\
$\mathrm{Sd}_{3}\left(03^{\text {rd }}\right.$ December $)$ & $59.91 \mathrm{c}$ & $7 \mathrm{c}$ & $71 \mathrm{c}$ & $1.09 \mathrm{c}$ & $3.09 \mathrm{c}$ \\
LSD Value & $\mathbf{2 . 2 6}$ & $\mathbf{0 . 7 5}$ & $\mathbf{2 . 0 7}$ & $\mathbf{0 . 0 4}$ & $\mathbf{0 . 0 6}$ \\
Water Stress Levels & & & & & \\
No Stress (100\% FC) & $69.33 \mathrm{a}$ & $9 \mathrm{a}$ & $80 \mathrm{a}$ & $1.25 \mathrm{a}$ & $3.73 \mathrm{a}$ \\
Water Stress (60\% FC) & $64.61 \mathrm{~b}$ & $7 \mathrm{~b}$ & $71 \mathrm{~b}$ & $1.17 \mathrm{~b}$ & $3.48 \mathrm{~b}$ \\
LSD Value & $\mathbf{1 . 8 4}$ & $\mathbf{0 . 6 1}$ & $\mathbf{1 . 6 9}$ & $\mathbf{0 . 0 5}$ & $\mathbf{0 . 0 5}$ \\
Camelina Genotypes & & & & & \\
Camelina-618 & $67.26 \mathrm{a}$ & $8 \mathrm{a}$ & $79 \mathrm{a}$ & $1.22 \mathrm{a}$ & $3.62 \mathrm{a}$ \\
$\begin{array}{l}\text { Camelina-611 } \\
\text { LSD Value }\end{array}$ & $66.61 \mathrm{a}$ & $8 \mathrm{a}$ & $78 \mathrm{a}$ & $1.20 \mathrm{a}$ & $3.59 \mathrm{a}$ \\
\hline
\end{tabular}

Means sharing similar letter in a column are statistically non- significant $(\mathrm{P}>0.05)$
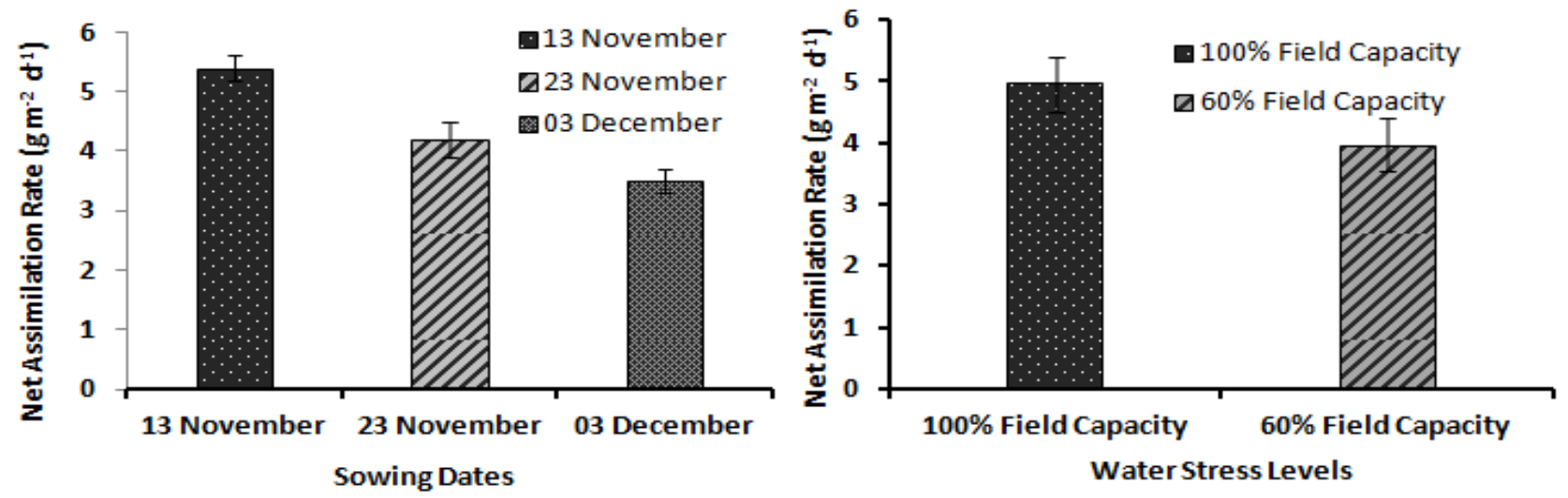

Figure 4: Net assimilation rate of Camelina sativa as affected by sowing date and water deficit stress

effects (planting date and water levels) for yield and yield contributing components but all the interaction effects were found to be non-significant for all these parameters. Data regarding yield and yield components indicated that maximum plant height, more number of branches per plant, highest number of pods per plant, 1000-seed weight and seed yield per plant were recorded in the early sowing date where plants were sown on $13^{\text {th }}$ November as compared to $2^{\text {nd }}\left(23^{\text {rd }}\right.$ November $)$ and $3^{\text {rd }}\left(3^{\text {rd }}\right.$ December $)$ sowing dates respectively (Table.4). In case of water regimes, plants grown with $60 \%$ FC showed less taller plants, lowest number of branches per plant, number of pods per plant, 1000-seed weight and less seed yield per plant compared with normally irrigated (100\% FC) plants (Table.4). Statistically no significant difference was observed between camelina genotypes regarding yield and yield attributes (Table 4).

\section{Discussion}

Sowing date is probably the most important component of crop management. Because the time required for crop development is directly linked with different environmental factors coming ahead in the whole growth phase of the plant (De Bruin and Pederson, 2008). Leaf area and leaf photosynthetic efficiency are two fundamental factors that drive crop growth. Results in our study indicated maximum LAI in $1^{\text {st }}$ planting date because plants had long growth duration, received more heating units and utilized sufficient photosynthetic materials resulting in more leaf area at flowering stage (65 DAS) (Yadavi et al., 2015) and after that leaf area decreased due to shading of the lower leaves, mobilization of nutrients from leaves to grains and leaf senescence until harvesting time reached (Sharifi et al., 2011; Toyota et al., 2003). Delay in planting reduced LAI due to reduction in growth duration (meeting uncomfortable 
environmental conditions) (Munakamwe, 2008). Drought stress imposed during vegetative phase of growth caused shrinkage leaves leading to yellowing and aging of leaves (Cakir, 2004). Inhibition of expansion of developing foliage and reduced size of younger leaves could be resulted in reduced LAI under water deficit conditions (AcostaGallegos and White, 1995). Likewise, reduction in leaf area index due to limited water supply in sunflower crop was reported by Sadras et al. (1993).

Findings of our study revealed maximum crop growth rate due to early planting ( $13^{\text {th }}$ November) and decreased CGR with delayed planting. In early planting $\left(13^{\text {th }}\right.$ November) CGR increased faster than other two planting dates mainly due to rapid leaf area development, that received more radiation thus synthesizing more photosynthates used for plant growth and development. Our results are in line with Kamali et al. (2014) and Yadavi et al. (2015) who reported similar trend of CGR in barley and white beans grown under different sowing dates. Reduction in CGR under delayed planting occurred due to sub optimum temperature during the vegetative growth phase, as leaf development and dry matter accumulation greatly depends on temperature (Warrington and Kanemasu, 1983). Reduction in CGR under drought stress occurred mainly due to increased respiration and decreased photosynthetic efficiency. Water deficit by reducing leaf area expansion and photosynthetic capacity decreases total dry matter and finally CGR, because leaf responds to water deficit through stomatal closure that limits $\mathrm{CO}_{2}$ supply to chloroplasts which ultimately decreases photosynthesis (Berkowitz et al., 1983; Muller and Whitsitt 1996). Our findings are in accordance with the conclusions of Goldani and Rezvani, (2007).

Results of present experiment showed that highest LAD was observed in $1^{\text {st }}$ planting date $\left(13^{\text {th }}\right.$ November $)$ and LAD decreased with late planting. These outcomes are in accordance with the findings of Yadavi et al. (2015) who described that in early planting maximum LAD is due to optimum utilization of resources and high photosynthetic activity. According to the findings of Munakamwe, (2008) reduction in growth duration is responsible for decreased LAD because day duration is reduced and less amount of radiation is absorbed leading to less photosynthetic efficiency. According to our results negative correlation has been found between water deficit and LAD. Water deficit slows down photosynthetic process, accelerates yellowing and induces faster aging of leaves which causes reduction in LAD. Similar findings were reported by Sharif, (1999) in cereals.

Net assimilation rate determined the amount of dry matter produced by leaves. Results of this study indicated that maximum NAR is recorded in the plants, planted on November 13. These conclusions are according to the verdicts of Khayat et al. (2015) who noted maximum NAR in early planted rapeseed genotypes mainly due to high photosynthetic activity. Delayed planting showed reduction in NAR because of increase in temperature, premature senescence and reduced LAI (Solymanzadeh et al., 2007; Din et al., 2011). Net assimilation rate is significantly reduced by drought stress in this study. As water deficit brings about stomata closure, photosynthetic rate decreases compared to crop leaf area, thus net assimilation rate reduces as well (Mojaddam et al., 2012). Our results are in agreement with Moradi et al. (2008) and Hejri et al. (2008) who reported significant decrease in NAR with increasing drought stress.

Results of yield and yield contributing components indicated that early planted $\left(13^{\text {th }}\right.$ November $)$ camelina produced maximum plant height, more number of branches per plant, more seed pods per plant, 1000-seed weight and maximum seed yield. Results from our study coincide with the conclusions of Chauhan et al. (1993) that increase in seed yield and yield related components due to early planting resulted from more absorption of light, water and minerals by plant canopies which resulted in increased photosynthetic efficiency. Gugel and Falk, (2006) also found that relatively cool and dry conditions favor high seed yields in camelina. Findings of our study are in accordance with Urbaniak et al. (2008) where they found correlation between number of branches per plant and number of pods per plant which was also highly correlated with seed yield in camelina. Higher thousand seed weight in early planting dates is also reported by Berti et al. (2011). Larger LAI, CGR and plant height have contributed towards higher yield in early planting (Yadavi et al., 2015).

Results of present study described that delay in planting negatively affected yield and yield contributing factors. In late planting, plant height reduced due to insufficient growth period and limited effect of environmental conditions (Rameeh, 2012). Delayed planting and end season heat contributed to physiological limitations in the flowering period. This happened due to poor growth of the plant or reduced leaf expansion. Therefore nourished ingredients had limited availability at the end of flowering, hence decrease in number of pods per plant occurred (Poriesa et al., 2007). 1000-seed weight decreased under late sowing because grain filling period had high temperatures that prevented maximum grain filling. Our results have conformity with the findings of other researchers (Rahnama and Bakhshandeh, 2005; Rabiee et al., 2004). Short growing season, reduction in flowering time, weak pollination and poor seed filling had 
contributed to reduce seed yield under late sown conditions (Uzun et al., 2009; Turhan et al., 2011).

Drought stress has adversely influenced the seed yield and yield related traits such as plant height, number of branches per plant, number of pods per plant, 1000-seed weight in Camelina sativa. Our results are according to the findings of Sangtarash et al. (2009) where they found decrease in plant height with imposed drought stress. Most sensitive yield component to drought stress is number of pods per plant (Diepenbrock, 2000). Apparently water deficit stress hindered flowering and reduced the possibility of developing flower into pod resulting in pod abortion (Kimber and McGregor, 1995). Reduced number of branches per plant is also in accordance with the findings of Halvorson et al. (2001) who reported that number of branches per plant entirely dependent on the supply of moisture during growth period. Decreased seed yield is the result of interrupted water supply from flowering to seed maturity stage (Sharghi et al., 2011). At the later stages of reproductive growth implication of water deficit stress reduces the source supply for seed yield by enhancing leaf shedding and accelerating maturity (Gan et al., 2004).

\section{Conclusion}

It is evident from this study that growth and yield of camelina genotypes is strongly influenced by sowing date and drought stress levels. Early planting ( $13^{\text {th }}$ November $)$ of camelina resulted in maximum LAI, CGR, LAD and NAR which in turn strongly correlated with maximum yield in camelina. Similarly maximum growth and yield was achieved with $100 \%$ field capacity level as compared to $60 \%$ field capacity.

\section{Acknowledgement}

Higher Education Commission of Pakistan is highly acknowledged for funding this project.

\section{References}

Acosta-Gallegos, J.A. and J.W. White. 1995. Phenological plasticity as an adaptation by common bean to rainfed environments. Crop Science 35: 199-204.

Araus, J.L., G.A. Slafer, M.P. Reynolds and C. Royo. 2002. Plant breeding and drought in $\mathrm{C}_{3}$ cereals: what to breed for? Annals of Botany 89: 925-940.

Aurore, B., R. Howard-Hildige, A. Connell, R. Nichol, J. Ryan, B. Rice, E. Roche and J.J. Leahy. 2003. Camelina oil as a fuel for diesel transport engines. Industrial Crops and Products 17: 191-197.

Berkowitz, G. A., C. Chen and M. Gibbs. 1983. Stomatal acidification mediates in vivo water stress inhibition of nonstomatal-controlled photosynthesis. Plant Physiology 72:1123-1126.

Berti, M., S. Wilckens, S. Fischer, A. Solis and B. Johnson. 2011. Seeding date influence on camelina seed yield, yield components and oil content in Chile. Industrial Crops and Products 349:1358-1365.

Bethlahmy and Nedavia. 1952. A method for approximating the water content of soils: Am. Geophys. Union Trans., v. 33, pt. 1, p. 699-706.

Bhuiyan, M.S., M.R.I. Mondol, M.A. Rahaman, M.S. Alam and A.H.M.A. Faisal. 2008. Yield and yield attributes of rapeseed as influenced by date of planting. International journal of Sustainable Crop Production 3: 25-29.

Cakir, R. 2004. Effect of water stress at different development stages on vegetative and reproductive growth of corn. Field Crops Research 89: 1-16.

De Bruin, J.L. and P. Pederson. 2008. Soybean seed yield response to planting date and seeding rate in the upper Midwest. Agronomy Journal 100: 696-703.

Diepenbrock, W. 2000. Yield analysis of winter oilseed rape (Brassica napus L.), a review. Field Crops Research 67: 35-49.

Din, J., S.U. Khan, I. Ali and A.R. Gurmani. 2011. Physiological and agronomic response of Rapeseed varieties to drought stress. Journal of Animal and Plant Sciences 21: 78-82.

Dornbos Jr. D. 2002. Production environment and seed quality. pp. 119-152. In: Seed quality: Basic mechanism and agricultural implications, CBS Publishers, New Delhi.

Gan, Y., S.V. Angadi, H. Cutforth, V.V. Angadi and C.L. Mc Donald. 2004. Canola and mustard response to short periods of temperature and water stress at different developmental stages. Canadian Journal of Plant Science 84: 697-704.

Gardner, C.M.K., D.A. Robinson, K. Blyth and J.D. Cooper. 2001. Soil water content. pp. 1-64. In: K.A. Smith, and C.E. Mullins, Soil and Environmental Analysis: Physical Methods. Marcel Dekker, New York.

Gesch, R.W. and S.C. Cermak. 2011. Sowing date and tillage effects on fall-seeded camelina in the northern corn-belt. Agronomy Journal 103: 980-987.

Goldani, M. and P. Rezvani. 2007. The effects of different irrigation regimes and planting dates on phenology and growth indices of three chickpea (Cicer arietinum L.) cultivars in mashhad. Journal of Agricultural Science 4: 1-12.

Gugel, R.K. and K.C. Falk. 2006. Agronomic and seed quality evaluation of Camelina sativa in western Canadian Journal of Plant Science 86: 1047-1058. 
Hakan-ozer, E.O. and D. Unsal. 1999. Relationships between yield and yield components on currently improved spring rapeseed cultivars. Turkish Journal of Agriculture and Forestry 23: 603-607.

Halvorson, A.D., B.J. Wienhold and A.L. Black. 2001. Tillage and nitrogen fertilization influence grain and soil nitrogen in annual cropping system. Agronomy Journal 93: 836-841.

Hejri, A. 2008. The effect of drought stress on growth indices, agronomical traits, yield and yield components of sunflower cultivars. MSc thesis. Agriculture faculty. Isfahan branch of Islamic Azad University.

Hrastar, R., M.G. Petrisic, I. Ogrinc and I.G. Kosir. 2009. Fatty acid and stable carbon isotope characterization of camelina sativa oil: implications for authentication. Journal of Agricultural and Food Chemistry 57: 579585.

Hunt R. 1978. Plant Growth Analysis. Studies in biology. Edward Arnold, London, 96: 26-38.

Kamali, N., M. R. Khajeh Pour and A. Soleymani. 2014. Studying growth indices and grain yield of barley cultivars at planting dates in Isfahan region. International Journal of Farming and Allied Sciences 3: 35-44.

Khayat, M., A. Rahnama, S. Lorzadeh and S. Lack. 2015. Growth analysis of rapeseed (Brassica napus L.) genotypes in different sowing dates under warm and semi-arid conditions in South West of Iran. Journal of Biodiversity and Environmental Sciences 6: 387-394.

Kimber, D.S and D.I. McGregor. 1995. Brassica Oilseeds: Production and utilization. 394 p. $1^{\text {st }}$ Ed. CAB International. Oxon UK.

Mojaddam, M., A. Shokuhfar and S. Lack. 2012. Effects of water stress and different levels of nitrogen on growth analysis parameters of sunflower. Journal of food, Agriculture \& Environment 10: 839-842.

Moradi, A., A. Ahmadi and A.H. Zadeh. 2008. The effects of different timings and severity of drought stress on gas exchange parameters of mung bean. Desert 13: 5966.

Munakamwe Z. 2008. A physiological study of weed competition in peas (Pisum sativum L.). A thesis submitted in fulfillment of the requirements for the degree of doctor of philosophy. Lincoln University. $164 \mathrm{p}$.

McVay, K. A. and Q.A. Khan. 2011. Camelina yield response to different plant populations under dryland conditions. Agronomy Journal 103: 4-1265.

Moloney, A.P., V.B. Woods and F.P. Omara. 2001. Characterization of feedstuffs for ruminants. In: Beef Production Series No.32. Department of Animal
Science and Production. Scotland, ISSBN 18841702110.

Muller, J. E. and M. S. Whitsitt. 1996. Plant cellular response to water deficit. Plant Growth Regulators 20: 41-46.

Pavlista, A.D., T.A. Isbell, D.D. Baltensperger and G. W. Hergert. 2011. Planting date and development of spring-seeded irrigated canola, brown mustard and camelina. Industrial Crops Production 33: 451-456.

Pilgeram, A.L., D.C. Sands, D. Boss, N. Dale, D. Wichman, P. Lamb, C. Lu, R. Barrows, M. Kirkpatrick, B. Thompson and D.L. Johnson. 2007. Camelina sativa, a Montana omega-3 and fuel crop. Pages in: Janick, J. and Whipkey, A. eds. Issues in new crops and new uses. ASHS Press, Alexandria, pp. 129-131.

Poriesa, M., M. Nabipor and R. Mamaqani. 2007. Phenological characteristics of rapeseed cultivars and four planting dates and their correlation with yield and yield components. Scientific Journal of Agriculture 30: 51-62.

Putnam, D. H., J. T Budin, L.A. Field and W.M. Beene. 1993. Camelina: A promising low-input oilseed. p. 314-322. In: J. Janick and J.E. Simon (eds.), New crops. Wiley, New York.

Rabiee, M., M.M. Karimi and F. Safa. 2004. Effect of planting date on grain yield and agronomic traits of rapeseed cultivars as a second crop after rice in Kochesfahan region. Iranian Journal of Agricultural Sciences 35: 177-187.

Rahnama, A.A. and A. Bakhshandeh. 2005. Effect of sowing dates and direct seeding and transplanting methods on agronomic characteristics and grain yield of Canola under Ahvaz conditions. Iranian Journal of Crop Sciences 7: 324-336.

Rameeh, V. 2012. Evaluation of the planting dates effects on yield and yield associated traits in rapeseed advanced lines. International Journal of Agriculture innovation and Research 1: 7-11.

Reddi, G.H.S. and T.Y. Reddi. 1995. Irrigation of principal crops, In: Efficient use of irrigation water, 2nd edn, Kalyani Publishers, New Delhi, India, pp. 229-259.

Sadras, V.O., F.J. Villalobos and E. Fereres. 1993. Leaf expansion in field grown sunflower in response to soil and leaf water status. Agronomy Journal 85: 590-611.

Sangtarash, M.H. 2009. Differential sensitivity of canola (Brassica napus) seedlings to ultraviolet-B radiation, water stress and abscisic acid. Environmental and Experimental Botany 66: 212-219.

Sharifi, R.S., H. Bigonah and J. Azimi. 2011. Plant population influence on the physiological indices of wheat (Triticum aestivum L.) cultivares. International Research Journal of Plant Science 2: 137-142. 
Sharghi, Y., A.H. Shirani rad, A. Ayene band, G. N. Mohammadi and H. Zahedi. 2011. Yield and yield components of six canola (Brassica napus L.) cultivars affected by planting date and water deficit stress. African Journal of Biotechnology 10: 9309-9313.

Sharif, M. 1999. Effect of irrigation at different growth and yield performance of wheat cultivars. M.Sc. Agri. Thesis, Univ. Agri., Faisalabad, Pakistan.

Shonnard, D.R., L. Williams and T.N. Kalnes. 2010. Camelina-derived jet fuel anddiesel: sustainable advanced biofuels. Environmental Progress \& Sustainable Energy 3: 382-392.

Singh, M.P., U.N. Pandey, R.K lal and G.S. Chaturvedi. 2002. Response of Brassica species to different irrigation regimes. Indian Journal of Plant Physiology 1: 66-69.

Solymanzadeh, H., N. Latifi and A. Soltani. 2007. Phenological and physiological traits associated with grain yield of Rapeseed cultivars under rain-fed conditions. Journal of Agricultural Sciences and Natural Resources 14: 67-76.

Steel, R.G.D., J. H. Torrie and D.A. Dickey. 1997. Principles and procedures of statistics: a biometric approach, 3rd Ed. McGraw Hill Book Co. Inc., New York. USA.

Tabassum, M.I. 2004. Development of maize under water stress areas. Published in DAWN, Internet Edn., November 14, 2004.

Toyota, M., F. Shiotsu, J. Bian, M. Morokuma and A. Kusutani. 2003. Effects of radiation in plant height induced by chlormequat on Radiation Interception and Radiation Use Efficiency in Wheat in Southwest Japan. Plant Production Science 13: 67-73.

Turhan, H., M.K. Gul, C.O. Egesel and F. Kahriman. 2011. Effect of sowing time on grain yield, oil content, and fatty acids in rapeseed (Brassica napus). Turkish Journal of Agriculture and Forestry 35: 225-234.

Urbaniak, S.D., C.D. Caldwell, V.D. Zheljazkov, R. Lada and L. Luan. 2008. The effects of seeding rate, date and seeder type on performance of Camelina sativa L. in the Maritime Provinces of Canada. Canadian Journal of Plant Science 88: 501-508.

Uzun, B., U. Zengin, S. Furat and O. Akdesir. 2009. Sowing date effects on growth, lowering, seed yield and oil content of canola cultivars. Asian Journal of Chemistry 21: 1957-1965.

Vollmann, J., T. Moritz T.C. Kargl, S. Baumgartner and H. Wagentrist. 2007. Agronomic evaluation of camelina genotypes selected for seed quality characteristics. Industrial Crops and Products 26: 270-277.

Walton, G. and B. Bowden. 1999. Environmental impact on canola yield and oil. Proceedings of the Tenth International Rapeseed Congress, Canberra, Australia, 6-10.

Warrington, I.J. and E.T. Kanemasu. 1983. Corn growth response to temperature and photoperiod II. Leafinitiation and leaf-appearance rates. Agronomy Journal 75: 755-761.

Watson, D.J. 1947. Comparative physiological studies in the growth of field crops. Variation in net assimilation rate and leaf area between species and varieties, and within and between years. Annals of Botany 11:41-76.

Yadavi, A., M. Kiani, M. M. Dehnavi and R. Khajeeyan. 2015. Sowing date and weed competition effects on growth, phenology and yield of three white bean (Phaseolus vulgaris L.) cultivars. International Journal of Biological Sciences 6:80-89.

Zubr, J. 1997.Oil-seed crop: Camelina sativa. Industrial Crops and Products 6: 113-119. 